\title{
Effect Of Consumer Value, Consumer Experience And Service Quality Of Customer Loyalty Through Consumer Satisfaction (Case Study On Beauty Care In Cilacap)
}

\author{
Nandang Bekti Karnowati ${ }^{1}$, Herni Justiana Astuti ${ }^{2}$ \\ \{1nandangbekti6633@gmail.com, ${ }^{2}$ herni99@gmail.com\} \\ Master of Management, Universitas Muhammadiyah Purwokerto
}

\begin{abstract}
This study aims to analyze the effect of consumer value, customer experience, service quality to customer loyalty trhrought customer satisfaction. This study uses a purposive sampling technique with 84 respondents who are beauty clinic patients who have changed services from previous beauty clinics and are currently using beauty care for 1 year at the current beauty clinic. Questionnaire data were processed using Partial Least Square (PLS) analysis with testing measurement model (outer) model and inner model with path coefficient. The results of the analysis show that consumer value and service quality have a positive effect on customer satisfaction. The consumer experience variable has a positive effect on customer loyalty. However, the consumer value of customer service quality and customer satisfaction does not affect to customer loyalty. While consumer experience has no effect on customer satisfaction. The variable customer satisfaction is not able to mediate consumer value, consumer experience and service quality to beauty care loyalty.
\end{abstract}

Keywords: consumer value, customer experience, service quality, customer satisfaction, customer loyalty.

\section{Introduction}

The cosmetics market industry is currently growing. Consumer attention to beauty treatments is increasing as the times develop. Beauty care is a necessity for women to support an increasingly attractive and perfect appearance. The beauty care clinic business is becoming increasingly popular with entrepreneurs. Intense competition offers a wide range of quality products and convenience facilities. The consumer is the most important asset in a company. A good company is one that maintains its relationship with consumers or customers. Maintaining customers by fostering good relationships will create loyalty. To realize customer loyalty the company must know the value desired by consumers. Value is the comparison between the benefits obtained by consumers from a product or service with the sacrifice of consumers to obtain and use these products[1].

Consumer experience is a growing phenomenon in marketing research and a priority because consumer experience is a quality perceived by consumers in competitive competition. Consumer experience is interpreted as a real response to consumers as a whole of consumer perceived results on company performance[2]. A good experience that is felt by consumers will make consumers want to buy back which is the beginning of a loyalty. Quality is the fulfillment of customer expectations from a service [3]. Customers have a variety of expectations for various types of services. Maintaining quality and customer satisfaction is the 
key to being able to retain customers and increase profitability. Consumer satisfaction is a complex phenomenon that involves the expectations and experiences of consumers [4]. Good service quality and positive customer experience is the beginning of the formation of a customer satisfaction.

Consumer loyalty is a company's main goal to be able to keep customers loyal to use the company's products or services and not switch to other brands. The company will make consumers as loyal customers by trying to increase value and quality and provide an interesting experience for consumers.

Based on the description above, researchers are interested in designing models that cause consumers to become loyal. Is the consumer value, customer experience, service quality and customer satisfaction that affect customer loyalty?

\section{Literature Review}

\subsection{Customer Loyalty}

Loyalty is the attitude of consumers' willingness to buy and use a company's product or service for a long period of time [5]. Customer loyalty is a continuation of the attitude of consumers who are satisfied in using the facilities and services provided by the company with the aim that consumers remain customers in the company [3]. The definition of a loyal consumer is someone who does the activity of buying goods or services repeatedly, has a positive attitude towards the company and considers to buy back the product or service when the consumer needs the same product or service [6].

\subsection{Consumer Value}

Marketing is closely related to efforts to create and deliver value to customers. Kotler (2007) defines customer value as the difference or comparison between the total value received by the customer and the total cost incurred by the customer. Value of the customer (customer value) is determined by the difference in total benefits and the total costs incurred by customers to obtain and use the product [3]. Customer's value is the difference between the total value of the benefits received by the customer divided by the total costs incurred by the customer [1]. The value received can direct directly to the formation of feelings of overall satisfaction. The research results of Hijjah et al show that customer value variables have a positive effect on customer loyalty[7]. The results of Mokoagouw's et al show that customer value has a positive effect on satisfaction [8]. The statements of the researchers that have been described above; it can be concluded that a business venture that pays attention to customer value will produce a customer loyalty.

From the description above it can be proposed the following hypothesis:

H1: Consumer value has a positive effect on customer loyalty.

H2: Consumer value has a positive effect on customer satisfaction. 


\subsection{Consumer Experience}

Real experiences that are positive and meaningful will influence consumer behavior in the life of a consumer. Providing good or positive experience to customers can provide benefits such as minimizing negative communication and adding positive product or service information. Customer experience is interpreted as the result of interactions that occur between consumers and products or services that have been purchased from a company, causing positive or negative reactions [9]. Research conducted by Hijjah and Ardiansari shows that there is a positive effect of customer experience on customer loyalty and the results in customer experience research have a positive effect on customer satisfaction . From the description above it can be proposed the following hypothesis:

H3: Consumer experience has a positive effect on customer loyalty.

H4: Consumer experience has a positive effect on customer satisfaction.

\subsection{Quality of Service}

One important factor in shaping customer satisfaction is quality service. Quality is the company's effort to meet customer expectations presented in a service [3]. Consumers assess the quality of a product or service by comparing an existing internal standard before using the product or service. Service quality as an activity in an effort to provide what customers need in terms of products or services [10]. Research conducted by Rachelia [11] shows the results that service quality has a positive effect on customer loyalty. Research Muzammil et al shows the results of service quality have a positive effect on customer satisfaction [12].

From the description above it can be proposed the following hypothesis:

H5: Service quality has a positive effect on customer loyalty.

H6: Service quality has a positive effect on customer satisfaction.

\subsection{Consumer Satisfaction}

Satisfaction is a feeling of pleasure that consumers arise as a result of comparing the impression of reality received because the performance of the product or service used is in line with expectations [13]. Consumer satisfaction can influence desirable behavior, one of which is customer loyalty. Consumer satisfaction is the impression that arises in the form of a response to feelings due to the experience of consuming products or services, consumers feel the difference in expectations and real performance [14]. Research conducted by Muzammil et al shows the results of the positive influence of customer satisfaction on customer loyalty [12]. From the description above it can be proposed the following hypothesis:

H7: Consumer satisfaction has a positive effect on customer loyalty.

H8: Consumer satisfaction mediates the relationship of consumer value, consumer experience and service quality to customer loyalty 


\section{Method}

\subsection{Respondents}

Respondents are beauty clinic patients who have changed services from previous beauty clinics and are currently using beauty care for 1 year at the beauty clinic now.

\subsection{Data analysis}

The data in this study were analyzed using structural equation modeling with the Partial Least Square (PLS) approach.

\subsection{Research Actions}

PLS-SEM analysis usually consists of two sub-models, namely the measurement model or often called the outer model and the structural model or often called the inner model. Evaluation of the model using SmartPLS 3.2.8 can be done by assessing the results of the measurement model, namely through confirmatory factor analysis (CFA) by testing the validity and reliability of latent constructs (see table 1). Then proceed with structural model evaluation and significant testing to test the effect between constructs or variables.

Table 1. Evaluation Rules for the Success of the Measurement Model

\begin{tabular}{|c|c|c|}
\hline $\begin{array}{l}\text { Validity and } \\
\text { Reliability }\end{array}$ & Parameter & Rules of success \\
\hline Convergent Validity & Loading Factor & $\begin{array}{l}\text { 1.> } 0.70 \text { for confirmatory research } \\
\text { 2. } 0.50-0.60 \text { is still acceptable for the } \\
\text { development stage }\end{array}$ \\
\hline & $\begin{array}{l}\text { Average Variance } \\
\text { Extracted (AVE) }\end{array}$ & $>0.50$ for confirmatory and exploratory research. \\
\hline Reliability & Composite Reliability & $\begin{array}{l}\text { 1. } 1 .>0.70 \text { for confirmatory research } \\
2 .>0.60 \text { is still acceptable for the initial stages } \\
\text { of development. }\end{array}$ \\
\hline
\end{tabular}

After the outer model meets the criteria the next step is to test the inner model.

\section{Result And Discussion}

\subsection{Response Rate}

The response rate of the questionnaire in this study was $92.4 \%$. The total number of respondents was 84 people. Respondents are beauty clinic patients who have changed services from previous beauty clinics and are currently using beauty care for 1 year at the beauty clinic now. 


\subsection{Outer Model}

The measurement model can proceed to the next stage, namely the inner model if the outer model results meet valid and reliable criteria. In table 2 can be seen the measurement model of the study. All indicators can be accepted because it has a loading factor above 0.5 . This model can be said to be reliable if the value of composite reliability is more than 0.6. In the table it can be seen that all variables meet the criteria that can be relied upon.

Table 2. Variables, Indicators, Loading Factors, AVEs and Composite Reliability

\begin{tabular}{|c|c|c|c|c|}
\hline Variables & Indicators & $\begin{array}{l}\text { Loading } \\
\text { Factors }^{\mathrm{a}} \\
\end{array}$ & $\mathrm{AVEs}^{\mathrm{b}}$ & $\begin{array}{l}\text { Composite } \\
\text { Reliability }^{\mathrm{c}}\end{array}$ \\
\hline \multirow{4}{*}{$\begin{array}{l}\text { Customer Value } \\
\text { (Tjiptono,2014) }\end{array}$} & Performance value (NK1) & 0.807 & 0.555 & 0.831 \\
\hline & Sosial value (NK2) & 0.693 & & \\
\hline & Emotional value (NK3) & 0.835 & & \\
\hline & Price value (NK4) & 0.625 & & \\
\hline \multirow{5}{*}{$\begin{array}{l}\text { Consumer Experience } \\
\text { (Schmitt, 2005) }\end{array}$} & Sense (PK1) & 0.598 & 0.546 & 0.856 \\
\hline & Fell (PK2) & 0.739 & & \\
\hline & Think (PK3) & 0.799 & & \\
\hline & Act (PK4) & 0.736 & & \\
\hline & Relate (PK5) & 0.803 & & \\
\hline \multirow{5}{*}{$\begin{array}{l}\text { Service Quality } \\
\text { (Kottler\&Keller,2018) }\end{array}$} & Reliability(KL1) & 0.719 & 0.555 & 0.861 \\
\hline & Responsiveness (KL2) & 0.786 & & \\
\hline & Insurance(KL3) & 0.848 & & \\
\hline & Empathy (KL4) & 0.721 & & \\
\hline & Tangible Objects (KL5) & 0.631 & & \\
\hline \multirow{6}{*}{$\begin{array}{l}\text { Kepuasan Konsumen } \\
\text { (Astuti\&Nagase, } \\
2016 \text { ) } \\
\text { Loyalitas Pelanggan } \\
\text { (Astuti\&Nagase, } \\
\text { 2014) }\end{array}$} & Tratment experience (KK1) & 0.844 & 0.665 & 0.856 \\
\hline & Feeling happy or dissapointed (KK2) & 0.792 & & \\
\hline & Recommended to others (KK3) & 0.809 & & \\
\hline & Firmness (LP1) & 0.709 & 0.631 & 0.836 \\
\hline & Defense (LP2) & 0.858 & & \\
\hline & Repeat purchase (LP3) & 0.809 & & \\
\hline
\end{tabular}

AVE: Average Varian Extract

${ }^{\mathrm{a}}$ Acceptable value of Loading Factor is greater than 0.5

${ }^{\mathrm{b}}$ Acceptable value of AVE is greater than 0.5

${ }^{\mathrm{c}}$ Acceptable value of Composite Reliability is greater than 0.6

\subsection{Inner Model}

Evaluation of structural models aims to predict relationships between latent variables. The inner model is evaluated by looking at the percentage variance that is by looking at the RSquare value for the endogenous latent construct. Based on Figure 1, it can be seen that the value of R-square adjusted for customer satisfaction 0.472 means the contribution of consumer value, customer experience and service quality to customer satisfaction by $47.2 \%$. While consumer value, customer experience, service quality and customer satisfaction can explain the relationship with customer loyalty of $38.9 \%$. 


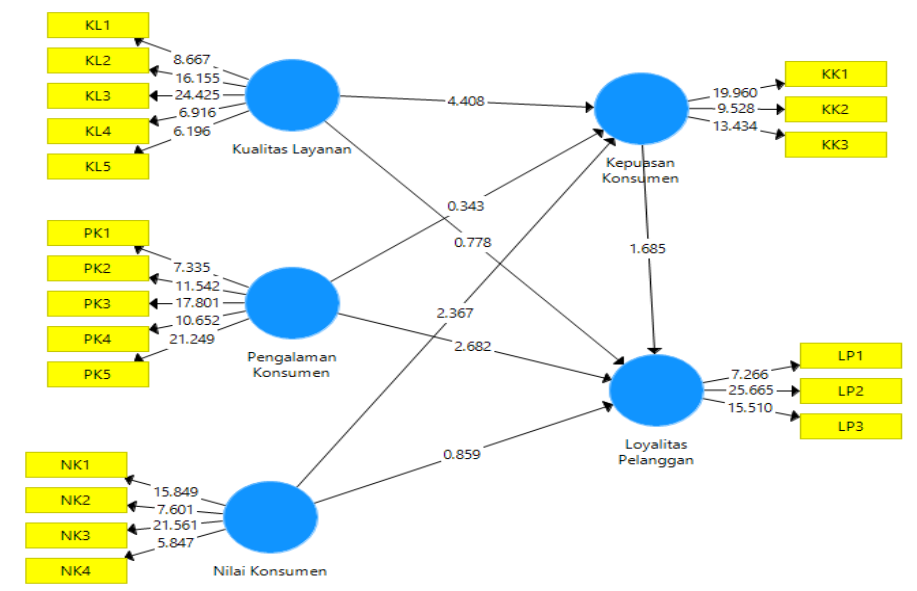

Fig.1. Structural equation of customer Loyalty in Beauty care

Based on the literature review that builds hypotheses, by looking at table 3 which explains the results of the relationship between the path coefficient and the $\mathrm{P}$ value, there are 3 accepted hypotheses and 7 rejected hypotheses. The table clearly shows a positive relationship between consumer value and customer satisfaction with a coefficient of 0.276 and a $\mathrm{P}$ value of $0.000<0.05$, which means the hypothesis is accepted. Consumer experience also has a positive effect on customer loyalty with a coefficient of 0.343 and a p value of $0.008<0.05$ means that the hypothesis is accepted. Service quality has a positive effect on customer satisfaction with a coefficient of 0.485 and a value of $0.000 p<0.05$ so that the hypothesis is accepted. Consumer value has no effect on customer loyalty with a coefficient of 0.102 but a value of P-value $0.391>0.05$ so the hypothesis is rejected. Consumer experience has no effect on customer satisfaction with a coefficient of 0.043 and P-value 0.732 so the hypothesis is rejected. Quality of service does not affect customer loyalty with a coefficient of 0.113 and a value of $0.437 \mathrm{P}$ value. Consumer satisfaction does not affect customer loyalty with a coefficient of 0.209 and a value of 0.093 so that the hypothesis is rejected.

Table 3. Relationships, Path Coefficients, $P$ Values, Results

\begin{tabular}{lccc}
\hline \multicolumn{1}{c}{ Relationships } & $\begin{array}{c}\text { Original } \\
\text { Sample }\end{array}$ & $\begin{array}{c}\mathrm{P} \\
\text { values }\end{array}$ & Results \\
\hline Customer Value $\rightarrow$ Customer Loyalty (H1) & 0.102 & 0.391 & Rejected \\
Customer Value $\rightarrow$ Customer Satisfaction (H2) & 0.276 & 0.018 & Accepted \\
Customer Experience $\rightarrow$ Customer Loyalty (H3) & 0.343 & 0.008 & Accepted \\
Customer Experience $\rightarrow$ Customer Satisfaction (H4) & 0.043 & 0.732 & Rejected \\
Service Quality $\rightarrow$ Customer Loyalty (H5) & 0.113 & 0.437 & Rejected \\
Service Quality $\rightarrow$ Customer Satisfaction (H6) & 0.485 & 0.000 & Accepted \\
Customer Satisfaction $\rightarrow$ Customer Loyalty (H7) & 0.209 & 0.093 & Rejected \\
Customer Value $\rightarrow$ Customer Satisfaction $\rightarrow$ Customer Loyalty & 0.058 & 0.172 & Rejected \\
(H8) & & & \\
Customer Experience $\rightarrow$ Customer Satisfaction $\rightarrow$ Customer & 0.009 & 0.768 & Rejected \\
Loyalty (H9) & & & \\
Service Quality $\rightarrow$ Customer Satisfaction $\rightarrow$ Customer Loyalty & 0.101 & 0.150 & Rejected \\
(H10) & & & \\
\hline
\end{tabular}




\subsection{Consumer value has a significant positive effect on customer satisfaction}

This shows that the value of a beauty care clinic has a close relationship with customer loyalty. Value indicators consisting of performance value, social value, emotional value and price value need to be the company's attention to form good perceptions so as to create customer loyalty. Customer loyalty can be created by increasing the value of beauty care performance, which is complete service and facilities, a comfortable place and competitive prices with competitors. It is important for companies that at this time social value is a consideration for consumers to remain loyal or loyal to the company. Feelings are accepted in a social group because using beauty care products or services can form loyal attitudes of consumers.

\subsection{Consumer experience has a significant positive effect on customer loyalty}

Consumer experience has a close relationship with customer loyalty. Positive experiences of consumers while enjoying beauty care clinic services can influence consumers to come back when they need it again and end up being loyal customers. But conversely if consumers have a negative experience with beauty care services, it is likely that they will not come back when they need the same service. Companies need to pay attention to how to provide a memorable experience for consumers so that it can foster customer loyalty or loyalty.

\subsection{Consumer value does not affect customer loyalty}

The hypothesis is rejected; in this study the value of consumers has no effect on consumer loyalty. This research differs from Griffin's theory that companies must improve, improve or even change products or services to get loyal customers. The results of this study are different from previous research, Fawaidurrahman et al. [1] shows that customer value has an influence on customer loyalty. This research shows that increasing or decreasing consumer value does not guarantee consumers to remain loyal to beauty care. Companies must have other strategies to get loyal customers who continue to use their products and not switch to other brands when they get offers or promotions for other products or services that are more attractive.

\subsection{Consumer experience does not affect consumer satisfaction}

The hypothesis is rejected, in this study the experience of consumers has no effect on customer satisfaction. This shows that consumer satisfaction is not influenced by positive or negative impressions of the experience of beauty care clinic consumers. The results of this study different from the research by Foster [16] which show that customer experience has a positive effect on customer satisfaction. Beauty care consumers in this case do not consider it important to sense, feel, think, act and relate to get satisfaction. The level of customer satisfaction that is different between one customer to another is also one of the factors, for example consumers who have negative or positive experiences the previous beauty care was satisfied because it was close to the office or residence of the consumer or the beaty care clinic partnered with the company where the consumer worked. 


\subsection{Service quality has no effect on customer loyalty}

The hypothesis is rejected, in this study the quality of service has no influence on customer loyalty beauty care. This shows that whether or not a loyal customer is not affected by the quality of service in beauty care. This study is different from the result of research Muzammil et al which show that service quality has a positive effect on customer loyalty [12]. Basically, good service quality will affect customer loyalty. But in this study, it can be seen that service quality does not affect customer loyalty. This can happen because consumers do not really care about the level of service quality provided by beauty care clinics, but customers pay attention to other factors. Beauty care customers, in this case, may not underestimate the level of reliability, responsiveness, assurance, empathy and physical aspects to remain loyal and loyal customers.

\subsection{Consumer satisfaction does not affect customer loyalty}

The results showed that customer satisfaction did not affect customer loyalty. This shows that loyalty is not influenced by the high or low level of beauty care consumer satisfaction. This study is different from the results of research conducted by Muzammil et al [12] which show the results of the positive influence of customer satisfaction on customer loyalty. Basically, customers who are satisfied with the services of a company. However, in this study it can be seen that customer satisfaction does not affect changes in customer loyalty. This can happen because consumers do not really consider treatment experience, feeling happy or dissapointed and recommended to others to remain loyal to beauty care clinics, but have other factors. It could be that the consumer does not feel satisfaction in the service but remains loyal because the customer is a club member in a social group who uses the same beauty care service or because of the close distance.

\subsection{The influence of consumer experience on customer loyalty through customer satisfaction}

The results showed that consumer experience indirectly had no effect on customer loyalty. Customer satisfaction does not mediate customer experience with customer loyalty. This may imply that the level of consumer loyalty is not influenced by positive or negative consumer experiences. Consumers who have had both negative and positive experiences remain loyal customers. Consumers do not really care about their experiences and impressions of beauty care clinics to remain loyal or loyal customers.

\subsection{The influence of service quality on customer loyalty through customer satisfaction}

The results showed that service quality indirectly had no effect on customer loyalty to beauty care. Customer satisfaction does not mediate service quality on customer loyalty. It can be stated that the increase and decrease in customer loyalty is not influenced by the quality of beauty care consumer services. Consumers who feel the level of service with high quality should be satisfied with the beauty care and with that satisfaction the customer will become 
loyal. However, this research is not the case because consumers do not attach importance to the level of service quality to be loyal to beauty care.

\section{Conclusion}

The conclusions from the results of the research and discussion above are: (1) Consumer value has a positive effect on customer satisfaction. (2) Consumer experience has a positive effect on consumer loyalty. (3) Service quality has a positive effect on customer satisfaction. (4) Consumer value has no effect on customer loyalty. (5) Customer experience has no effect on customer satisfaction. (6) Service quality has no effect on customer loyalty. (7) Customer satisfaction has no effect on customer loyalty. (8) Consumer satisfaction does not mediate the relationship between consumer value, consumer experience and service quality.

\section{References}

[1] A. Rohman, Rachma, and A. Slamet, "Pengaruh Nilai, Kepuasan, Dan Inersia Terhadap Loyalitas Pelanggan Yang Berbelanja Melalui E- Commerce Pada Mahasiswa Feb Universitas Islam Malang," J. Ris. Manajmen Prodi Manaj. Unisma, pp. 82-94, 2019.

[2] F. Buttle, Customer relationship management: Second edition. 2008.

[3] F. Tjiptono, "Pemasaran Jasa - Prinsip, Penerapan, dan Penelitiab," in 1, 2014.

[4] H. J. Astuti and K. Nagase, "A framework for conceptualizing patient loyalty to healthcare organizations," Heal. Serv. Manag. Res., vol. 29, no. 3, pp. 70-78, 2016, doi: $10.1177 / 0951484816663562$.

[5] C. Lovelock and L. Wright, Manajemen Pemasaran Jasa, 2nd ed. Jakarta: INDEKS, 2007.

[6] H. J. Astuti and K. Nagase, "Patient loyalty to health care organizations: Strengthening and weakening (satisfaction and provider switching)," J. Med. Mark., vol. 14, no. 4, pp. 191-200, 2014, doi: 10.1177/1745790415578311.

[7] R. Hijjah and A. Ardiansari, "Pengaruh Customer Experience dan Customer Value Terhadap Customer Loyalty Melalui Customer Satisfaction," Manaj. Anal. J., vol. 4, no. 4, pp. 281-288, 2015.

[8] S. Mokoagouw, J. Massie, and R. Wenas, "Pengaruh Nilai Pelanggan Dan Kualitas Pelayanan Terhadap Kepuasan Dampaknya Terhadap Loyalitas Nasabah," Ris. Bisnis dan Manaj., vol. 6, pp. 241-258, 2018.

[9] K. Ariningsih and M. Rahayu, "Analisa Customer Value dan Customer Experience terhadap Customer Loyalty dengan Customer Satisfaction sebagai variabel intervening," UMP, 2015.

[10] C. Andreas and T. Yuniati, "Pengaruh Kualitas Produk Terhadap Loyalitas Pelanggan Dengan Kepuasan Sebagai Variabel Intervening,” Ilmu dan Ris. Manaj., vol. 5, no. 5, pp. 1-16, 2016.

[11] E. D. Rachelia, "Pengaruh Kualitas Pelayanan, Nilai Pelanggan Terhadap Loyalitas Pelanggan Melalui Kepuasan Pelanggan Pada Pelanggan Taksi Konvensional,” Adm. Bisnis, pp. 1-12.

[12] A. Muzammil, M. Yunus, and N. Darsono, "Magister Manajemen Fakultas Ekonomi dan Bisnis Universitas Syiah Kuala 2,3) Fakultas Ekonomi dan Bisnis Universitas Syiah Kuala," $J$. Manajmen dan Inov., vol. 8, no. 3, pp. 104-133, 2017.

[13] E. M. dan S. Sangadji, "Perilaku Konsumen : Pendekatan Praktis Disertai Himpunan Jurnal Penelitian.," Penerbit Salemba, 2013.

[14] F. Rangkuti, Customer Service Satisfaction \& Call Center Berdasarkan ISO 9001. 2013.

[15] I. Ghozali, Structural Equation Modeling, 4th ed. Semarang: BP UNDIP, 2015.

[16] B. Foster, "Pengaruh Pengalaman Belanja Online Produk Fashion terhadap Kepuasan dan Niat Beli Ulang Pelanggan Zalora serta Berrybenka,” Kontigensi, vol. 5, no. 1, pp. 68-76, 2017. 